\title{
THE STUDY OF VALUES REFLECTED IN SECONDARY LEVEL ENGLISH SYLLABUS OF W.B.B.S.E.
}

Pradipaditya Sing ${ }^{* 1}$ (iD

${ }^{{ }^{* 1}}$ M. Ed. Trainee of Ramakrishna Mission Sikshanamandira, Belur Math, Howrah, West Bengal, India

DOI: https://doi.org/10.29121/granthaalayah.v8.i12.2020.2696

Article Type: Research Article

Article Citation: Pradipaditya Sing. (2020). THE STUDY OF VALUES REFLECTED IN SECONDARY LEVEL ENGLISH SYLLABUS OF W.B.B.S.E. International Journal of Research GRANTHAALAYAH, 8(12), 141-148. https://doi.org/10.29121/granthaa layah.v8.i12.2020.2696

Received Date: 05 December 2020

Accepted Date: 31 December 2020

Keywords:

Value

Value Education

Ultramodern

Life Principle

Nonfiction

\begin{abstract}
Traditionally in Indian education system values and value education is an integral part which is lacking among the today's young generations. The objectives of this study are to find out how the English syllabus is helping the students inculcating values, to identify the types of values incorporated in English syllabus of W.B.B.S.E. For this study qualitative method has been undertaken and content analysis has been done. The major findings of this study are that prose lessons are mostly able to develop values among the students than nonfiction and poetry; Nonfiction, though it is little in number of lessons, has high efficiency in the development of values, the English syllabus of W.B.B.S.E is able to develop social values, moral values and national values.
\end{abstract}

\section{INTRODUCTION}

Human beings started dwelling all together since the time immemorial when they were in jungle. They learned that loneliness is preying by others and togetherness is feeling happy forever. When they began to live together automatically, they started to follow certain norms and rules which are approved by the others. These norms are called, in present days, values. It is very hard to define what value is but it is very easy to feel. If it is defined, it may be a life principle or philosophy of life which varies man to man, society to society, state to state but universally acceptable for the wellbeing of the human being and society.

Nowadays we are living in an ultramodern society where our every stapes is followed by the determination of science and technology; where technology is more trustworthy than a human being. It means one does depend to other and most horribly one does not care about others. This makes the downfall of the values which connects to the society, in broader sense, to the universe. In earlier days this moral value departed from the family and people from the surroundings but now it is in vain. The children are forced to join the rat race competition to achieve material achievement and pleasure. They are also morally degraded.

The value education becomes a matter of discussion in present days to get rid of social degradation. In this respect value education is must incorporated is the school curriculum. It is very necessary for the secondary students

(C) 2020 The Author(s). This is an open access article distributed under the terms of the Creative Commons Attribution License, which permits unrestricted use, distribution, and reproduction in any medium, provided the original author and source are credited. 
The Study of Values Reflected in Secondary Level English Syllabus of W.B.B.S.E.

because they are in adolescence period which very difficult period in the life. This is the most horrible stage of life when the children suffer from depression, indecision and distract from the right way. They sometimes involve in unsocial activities. That's why secondary stage education is the right time which influence the pupil to be a good citizen. It becomes very necessary to incorporate value education in secondary syllabus especially in English language study where various stories help to develop both language competency and knowledge of various values.

English is the global language and one must have to know English to communicate with others in the outside of the country. So, every education system has adopted to teach English language as a subject which is taught in the schools in India as a 1st language or 2nd language. Again, it is very easy to deliver value education with various types of value related stories, essays, poems etc.

Now the time has come to think over it to maintain the values in the society. Education itself depends on certain values but in modern age the society is degrading and departed from values. That's why social unrest occurs in the society. To maintain this English is very helpful and if the feeling of value has to grow among the students the English is very important subject and it can take an effective part to develop it. In this respect how far, the present syllabus is appropriate to achieve this goal needs to be verified.

\section{REVIEW OF THE RELATED LITERATURE}

Gupta, R. R. (1987) made a study which aimed at identifying the values adhered to by pupil-teachers. The sample included 90 rural and 40 urban pupil-teachers of Amethi. Hindi version of Alport-Vernon-Lindzey study of Value Scale was used. Mean and S.D. were obtained. Rural student-teachers were higher in religious values than the urban student teachers. However, urban student-teachers were higher in political and economic values than rural student-teachers. The aesthetic theoretical and religious values of male student-teachers were higher than of female student- teachers.

Bhatia \& Dash (2011) did a comparative study of value based higher education system of six countries - UK, China, Australia, Brazil, and South Africa with India. The objectives of this study are to find the factors to innovate value based higher education system, to give suggestions for improving higher education system. The data is collected from the secondary sources of research reports, journals and research papers.

Talts, L., Kukk, A., Tuisk, M. \& Kaljuve, M. (2012) made a study to explore primary school teachers' beliefs about learning and teaching and to analyse their realisation proceeding from the principles of child-centred pedagogy. The aim was this study was to clarify which teaching related values primary school teachers most appreciated. The teachers' opinions were collected from the 357 primary school teachers from various regions of Estonia. The finding of this study was that the primary school teachers depended on learning and teaching related values prescribed by National Curriculum and applies principles of child- centred pedagogy.

Patil (2013) conducted a study on role of value-based education in society to review different options of scholars and implementation in present education system and role of the value education in the society. The study was done on the basis of secondary data. This study showed how value education can develop physical, mental, intellectual, emotional and spiritual values to enrich the life of an individual.

Cubukcu (2013) conducted a study to explore the values which pre-service english teachers have. In depth interview and survey method was adopted for this study.

Bernardo, Clemente, \& Liem (2014) tried to describe the values of Filipino adolescents: a comparison with pan-cultural norms. The researchers wanted to describe the value of Filipino adolescents and to find out how pancultural comparisons can complement emic approaches to studying values. Data was collected from 752 adolescents with the Portrait Values Questionnaire and a confirmatory factor analysis was done. The result of the study reveals that Filipino adolescents are subsequently similar to the pan-cultural student norms and they gave higher ranking for hedonism and stimulation and lower ranking for achievement.

Paula \& George (2014) made a study focusing on the role of cultural values and how it helps to promote chastity. A survey and in-depth interview were done to collect data from the female adolescents and their families. In this study quantitative and qualitative research method is done to find out the successive result. The result of this study was that the media does not play any effective role to encourage adolescents to remain chaste and the role of family in maintaining moral sanctity cannot be over emphasised as the family is the primary agent of socialization.

Mello, Jing, Armumugam \& Noh (2015) made an observation and semi-structured interview to investigate the effect of narrating moral stories using storyboard on students in two primary schools taking 57 children aged 7. 
The study resulted that the use of the use of storyboard for moral stories is an effective tool for primary schools and it also proved that the children tried to internalise the values demonstrated by the characters of the moral stories. This value-based story is very helpful to arouse self-esteem.

Finlay, Wray-Lake, warren \& Maggs (2015) endeavoured to study whether adolescent future values in six denominations (i.e., family responsibility, full-time job, personal responsibility, autonomy, civic responsibility, and hedonistic privilege) predicated adult social roles, civic behaviours, alcohol use. The data was collected from ages 16 and 34 and included 11,545 individuals. Descriptive statistics was made to find out the result of the study. The result suggests that the special attention should be paid to how adolescents are thinking about their futures due to the associated links with long-term social and health behaviours.

Vaičekauskienè (2015) made a study to highlight the conative expression of moral values in modern teenagers of early adolescents. The objectives of this study were to discuss the authenticity, responsibility and dignity, as the core of moral values education in early adolescents; to highlight the characteristics of empirical expression of authenticity, responsibility and dignity towards others in early adolescents; Compare the attitudes of 5 - 6 th graders, their parents and teachers towards the moral behaviour of pupils. The theoretical, empirical \& structural method is used for this study. The result of this study was that the early adolescents are self-centrical and they asses their moral behaviour more strictly than the behaviour of their peers.

Marks, Christian \& Graive (2015) conducted a mixed method study to find out the relationships exist between measures of students' values literacy and students' values internalisation and measures of gender, school size and years in the school and the correlation exists between measures of students' values literacy and students' values internalisation. The study resulted that Year Seven students had a varied knowledge and understanding of the Nine Core Values for Australian Schooling that appeared independent of background variables. The participants generally had sound levels of internalisation of values, but that the levels of internalisation among girls exceeded that among boys. Lastly there is no relationship between the knowledge of values and the internalisation of values.

Chowdhury (2016) examined how rapid science and technological advancements and globalization are affecting to the complexities in social life and underpinning the importance of morals, values and ethics. A comparative study has been made between the philosophical and theoretical basis of modern Western moral education and the universal Islamic moral values and education. It suggests a range of teaching, learning and pedagogical techniques to foster morals, values and ethics in students' mind.

Abrar's (2016) attitude was to portray ethical values in three selected English stories i.e. "The Rabbit and the Turtle, The Fox and the Goat, and the Monkey and the Crocodile" and to correlate with the values of real life and Islamic views. Qualitative research design and descriptive analysis had been adopted for this study. The study revealed that each story has moral lesion in its narrative.

Garg, Shivranjan \& Sharma (2017) had made a study to review various opinions about values given by various scholars and their importance in the field of education and their need and role in value-based education in the society. The study was done with the secondary data collected from the different books and web sources. The researcher concluded that value education is necessary in every institution to cultivate the feeling of success on the basis of values.

Bhakta \& Dutta (2017) had made a qualitative study to find out the importance of moral values, the causes \& consequences of moral degradation and the remedies to reduce the moral degradation among Indian youths. This study concludes that the value is very important in present days and the cause of value degradation is due to excessive use of scientific and technical interventions. The remedy of this grave problem is value education.

Shobana \& Kanakarathinam (2017) had attempted to analyse the need and awareness of the value education for students by the perception of teachers in Pollachi region. The objectives of this study were to find the factors influenced as ethical values among teachers, to know the perception of faculties for the need of ethic in education curriculum, to analyse the values that transform the character of the students, to know the values that influence the balanced life in future. The data is collected from randomly selected different departments of colleges in Pollachi region by using five-point likert scale. With this study it found that the teachers are ethically aware and they also depart ethical awareness to the students.

Gul143(2017) studied the concept and importance of value education and explained the role of teachers to promote values. Qualitative analysis had been made with the secondary sources of books, magazines, journals, newspapers and websites. The researcher concludes that only an ideal teacher whose life itself is a beacon light of values can lead a society in the right direction. For the sustainable human development as well as for the social 
growth, there is a need of value-based education, spiritual education, ethical education, as well as need-based education.

Lakshmi \& Paul (2018) made a study on value education in educational institutions and the role of teachers in promoting the concept. The objectives of this study were to understand the need, aim and objectives of the value education, to study about the Evolution of the 'Value Education' Concept in India, to explore some of the value education policies followed around the world and to define the role of Teachers in Value Education and suggest some improvements in the existing Value Education programme. The study was conducted on the basis of secondary data.

Fu, Lv, Yang, Yu \& Wang (2018) had studied a sample of 434 Chinese adolescents to find out how the special cultural value and the adolescent social behaviour would influence each other over time. It is a longitudinal study. After this study the researchers found that the earlier prosocial behaviour toward powerful people was positively correlated to subsequent power distance value, but not vice versa.

\section{RATIONAL FOR THE STUDY}

It has been found that the researchers had made various studies on value education in various perspective but the values in secondary English syllabus has been remained untouched. One had studied on various English stories but they are not strongly related to the school curriculum. Only the four short stories have been studied. So if the secondary level English class is to be studied, it will be a new beneficial work for the syllabus justification.

\section{OBJECTIVES OF THE STUDY}

Objective 1 - To find out how the English syllabus is helping the students inculcating values. Objective 2 - To identify the types of values incorporated in English syllabus of W.B.B.S.E.

\section{RESEARCH QUESTIONS}

\section{Objective 1-}

1) How does poetry help to develop values among the students?

2) How does prose help to develop values among the students?

3) How does non-fiction help to develop values among students?

\section{Objective 2-}

4) iv) Which type of values does the poetry develop?

5) v) Which type of values does the prose develop?

6) vi) Which type of values does the non-fiction develop?

\section{METHODOLOGY}

In this study certain methodologies had been adopted. The qualitative method had been applied for this study. The critical analysis had been done to find out the elements of values in English text books of class IX and X of W.B.B.S.E.

\subsection{SOURCE OF DATA}

The primary data had been collected from the text books of class IX and X and the secondary data had been gathered from the various reports of councils and commissions, books, articles, websites.

\section{DELIMITATIONS}

This study has been conducted only on the basis of the English textbooks of secondary level of Bengali medium schools of West Bengal Board of Secondary Education which is taught as a second language. 


\section{OBJECTIVE WISE FINDINGS}

The English textbooks of class-IX and X for Bengali medium school of W.B.B.S.E. have 8 poetry (4-IX, 4-X), 9 prose (6-IX, 3-X) and 4 nonfiction (2-IX, 1-X) having the ability to develop values in various rate.

Objective 1- To find out how the English syllabus is helping the students inculcating values.

\section{Answer to Research Questions:}

1) How does poetry help to develop values among the students?

2) How does prose help to develop values among the students?

3) How does non-fiction help to develop values among students?

Table: 1 Potentiality of Poetry, Prose and Nonfiction for the development of Values

\begin{tabular}{|c|c|c|c|c|c|c|}
\hline \multirow{2}{*}{ Genre } & \multicolumn{2}{|c|}{ Lessons Able to Develop values } & \multicolumn{2}{c|}{ Lessons Unable to develop Values } & \multicolumn{2}{c|}{ Total } \\
\cline { 2 - 7 } & No. & Percentage (\%) & No. & Percentage (\%) & No. & Percentage (\%) \\
\hline Poetry & 3 & 37.5 & 5 & 62.5 & 8 & 100 \\
\hline Prose & 7 & 77.8 & 2 & 22.2 & 9 & 100 \\
\hline Nonfiction & 2 & 66.7 & 1 & 33.3 & 3 & 100 \\
\hline Total & 12 & 60 & 8 & 40 & 20 & 100 \\
\hline
\end{tabular}

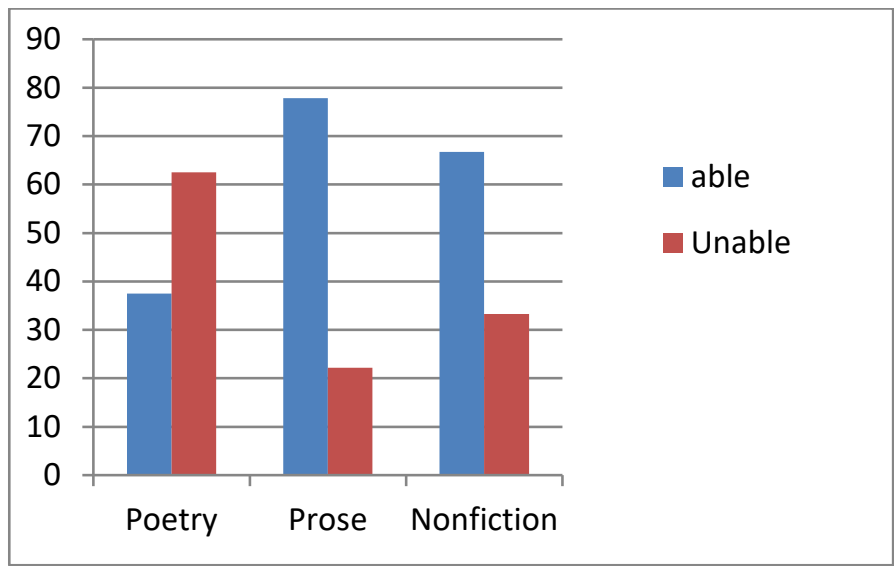

Figure 1: Percentage of Lessons of Poetry, Prose and Nonfiction Responsible for the Development of Values

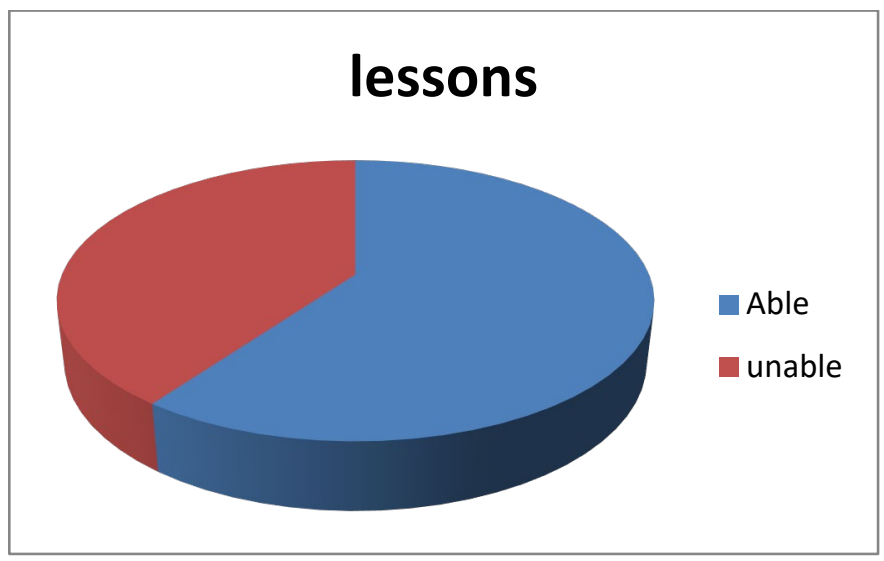

Figure 2: Percentage of Lessons of Textbooks Responsible for Development of Values

From table no. 1 it is found that $77.8 \%$ of the prose lessons are able to develop values out of all prose in the secondary syllabus of textbooks. On the other hand, $37.5 \%$ of poetry and $66.7 \%$ of nonfiction can develop values. Though number of nonfictional lessons in the textbooks is very small in number, it is better than poetry. 
So, it is clear that majority of the prose lessons are able to develop values in respect to other lessons. With the content analysis it is found that the proses are taken from various long stories which are presented in abridged version. Both the textbook of class IX and X are able to develop values. Sixty percent of texts are able to develop different values.

Table: 2 Overall lessons, Able to Develop Values

\begin{tabular}{|c|c|c|}
\hline \multirow{2}{*}{ Genre } & \multicolumn{2}{|c|}{ Lessons Able to Develop values } \\
\cline { 2 - 3 } & No & Percentage (\%) \\
\hline Prose & 3 & 25 \\
\hline Poetry & 7 & 58.3 \\
\hline Nonfiction & 2 & 16.7 \\
\hline Total & 12 & 100 \\
\hline
\end{tabular}

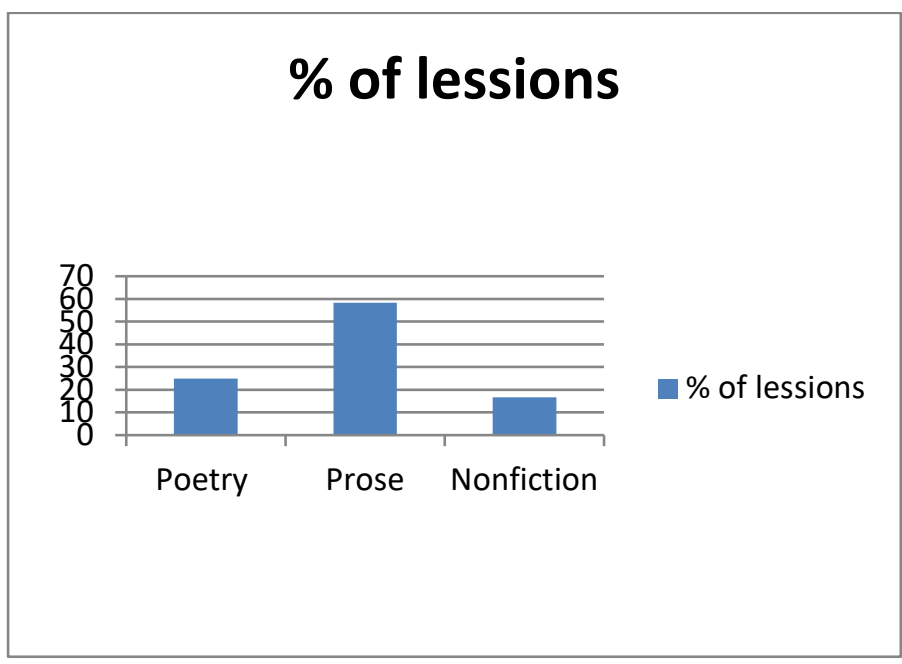

Figure 3: Percentage of Lessons of Poetry, Prose and Nonfiction Able to Develop Values

From the table no 2 it is proved that majority of prose lessons are able to develop values. Among the all lessons which can develop values, $58.3 \%$ prose lessons can able to develop values. With this it is clear that poetry has fewer competencies in the perspective of value education. Nonfiction is also able to develop values but it is very little in number included in the texts.

Objective 2- To identify the types of values incorporated in English syllabus of W.B.B.S.E.

\section{Answer to Research Questions:}

1) Which type of values does the poetry develop?

2) Which type of values does the prose develop?

3) vi) Which type of values does the non-fiction develop?

Table: 3 Types of Values Developed by Poetry, Prose and Nonfiction

\begin{tabular}{|c|c|c|c|c|c|}
\hline Genre & Social Values & Moral Values & Spiritual Values & National Values & Religious Values \\
\hline Poetry & Yes & Yes & - & - & \\
\hline Prose & Yes & Yes & & Yes & \\
\hline Nonfiction & Yes & Yes & - & Yes & \\
\hline
\end{tabular}

From the table no 3 It is very clear that poetry, prose and nonfiction, all these genres, mainly in secondary syllabus, can develop social and moral values. The last two genres can develop national values. But no genre can develop spiritual and religious values. Actually, all types of genre are able to develop values. It depends on the choice of the curriculum developers who will choose the Lessons. 


\section{ANALYSIS OF THE MAJOR FINDING}

To find out the efficacy of secondary English syllabus of W.B.B.S.E. in Bengali medium the qualitative method had been adopted and content analysis had been done. The result of this study has come that the English syllabus is able to develop social, moral and national values but it is unable to develop spiritual values and religious values. The syllabus contains various prose texts, poems, nonfiction dealing with different topics. With this study it is proved that the prose texts and the nonfictional texts play major role for the development of values. This is also supported by the opinion of the teachers who teach English as a subject. They are strongly agreed to the development of social values, moral values and national values. They are not agreed and not sure about the development of spiritual values and religious values but they are highly consent about the development of secularism.

\section{CONCLUSION}

With this study it is evident that the secondary English syllabus of W.B.B.S.E has the potentially for the development of values among the adolescent students. It rates of achievement depends on many other aspects for example teachers' teaching methods and skills, environment, family background etc. These are also the matters of research and new thing will also come out.

\section{SOURCES OF FUNDING}

This research received no specific grant from any funding agency in the public, commercial, or not-for-profit sectors.

\section{CONFLICT OF INTEREST}

The author have declared that no competing interests exist.

\section{ACKNOWLEDGMENT}

None.

\section{REFERENCES}

[1] Abrar, M. (2016). Learning from Fables: Moral Values in Three Selected English Stories. Dinamika Ilmu, Vol. 16, No. 1, 2016. https://www.researchgate.net/publication/305712762.

[2] Bhatia, k. \& Dash, M. K. (2011). A Demand of Value Based Higher Education System in India: A Comparative Study. Journal of Public Administration and Policy Research, Vol. 3(5), pp. 156-171. http://www.academicjournals.org/jpapr.Retrievedfrom https://www.researchgate.net/publication/228461431.

[3] Bernardo, A. B. I., Clemente, J. A. R., \& Liem, G. A. (2014). Describing the Values of Filipino Adolescents: A Comparison with Pan-cultural Norms. Journal of Tropical Psychology, Volume 4, e2, pp. 1-8. doi: 10.1017/jtp.214.2.

[4] Bhakta, k. \& Dutta, N. (2017). Degradation of Moral and Ethical Values Among Indian Youths: An Emerging Issue. International Education \& Research Journal (IERJ), Volume: 3, Issue: 5.

[5] Cubukcu, F (2013). Value Education Through Literature in English Classes. Elsevier Ltd., doi: 10.1016/j.sbspro.2014.01.206.

[6] Chowdhury, M. (2016). Emphasizing Morals, Values, Ethics, And Character Education In Science Education And Science Teaching. The Malaysian Online Journal of Educational Science, Volume 4, $\quad$ Issue 2.

[7] Chatterjee, N. (Sec.) Bliss, English Textbook for Class IX Second Language.

[8] Chatterjee, N. (Sec.) Bliss, English, Second Language, Class X. 
[9] Finlay, A., wray-Lake, L., warren, M. \& Maggs, J. L. (2015). Anticipating Their Future: Adolescent Values for the Future Predict Adult Behaviour. Department of Health \& Human Services. U S A. Int J Behav Dev. 2015 July 1; 39(4): 359-367. doi:10.1177/0165025414544231.

[10] Fu, X., Lv Y., Yang Z., Yu, X., Wang, R. (2018). Chinese Adolescents' Power Distance Value and Prosocial Behavior Toward Powerful People: A Longitudinal study. PLoS ONE 13(12): e0208473.https://do.i.org/10.1371/journal.pone.0208473.

[11] Gupta, R.R. (1987). A study of values of B.Ed. pupil-teachers of Avadh University. Indian Psychology Abstracts, 25 (3), 348. (Full article in Teacher Education, 1984, 19 (28\& 29), 43-46)

[12] Garg, V., Mr. Shivranjan \& Sharma, Mrs N. (2017). INDIAN SOCIETY AND VALUE BASED EDUCATION. International Journal of Science Technology and Management, Vol. No. 6, Issue No ６5, May 2017, Retrieved from https://www.researchgate.net/publication/330513958.

[13] Gul, S. B. A. (2017). Teacher and Value Education: An Exploratory Study, Peer - Reviewed Journal, Vol. 37. Retrieved from https://www.researchgate.net/publication/329012287.

[14] Lakshmi, v.v. \& Paul, M. M. (2018). VALUE EDUCATION IN EDUCATIONAL INSTITUTIONS AND ROLE OF TEACHERS IN PROMOTING THE CONCEPT. International Journal of Educational Science and Research, Vol. 8, Issue 4 , Aug 2018, 29-38. Retrieved https://www.researchgate.net/profile/M_Paul2/publication/327499925_VALUE_EDUCATION_IN_EDUCATI ONAL_INSTITUTIONS_AND_ROLE_OF_TEACHERS_IN_PROMOTING_THE_CONCEPT/links/5ba00fb3a6fdccd3 cb5ee7e8/VALUE-EDUCATION-IN-EDUCATIONAL-INSTITUTIONS-AND-ROLE-OF-TEACHERS-INPROMOTING-THE-CONCEPT.pdf

[15] Mello, G., Jing, H. F., Arumugam, N. \& Noh, M. A. M. (2015). Learning Values through Moral Stories Using a Storyboard. https://www.researchgate.net/publication/290004259.

[16] Paula, A. \& George, T. O. (2014). Waning Cultural Values and Adolescent Chastity: A Study of Arugba in $\begin{array}{lllll}\text { Nigeria.Developing } \quad \text { Country } & \text { Studies, } & \text { Vol.4, } & \text { No.4, }\end{array}$ https://www.researchgate.net/publication/322386621.

[17] Patil, Y. Y. (2013). Role of Value-Based Education in Society. Conference Paper. Retrieved from https://www.researchgate.net/publication/286933664

[18] Shobana, S. \& Kanakarathinam, R. (2017). Awareness and Need of Ethics and Values in Education for Students: A Study among College Teachers in Pollachi Region. IJCRR, Int J Cur Res Rev, Vol. 9, Issue 9, http://dx.doi.org/10.7324/IJCRR.2017.992631.

[19] https://en.wikipedia.org/wiki/Nonfiction

[20] Talts, L., Kukk, A., Tuisk, M. \& Kaljuve, M. (2012). Design for Learning and Teaching in the Context of Value Education. Procedia - Social and Behavioral Sciences 45 (2012) 75 - 83. Retrieved from https://cyberleninka.org/article/n/433358.pdf

[21] Vaičekauskienè, S. (2015). MORAL VALUES OF EARLY ADOLESCENTS: CONATIVE LEVEL. http://dx.doi.org/10.17770/sie2015vol2.441. 